$\begin{array}{lllllllllllllllllll}\mathrm{R} & \mathrm{E} & \mathrm{C} & \mathrm{E} & \mathrm{N} & \mathrm{Z} & \mathrm{J} & \mathrm{E} & \mathrm{I} & \mathrm{O} & \mathrm{M} & \mathrm{O} & \mathrm{W} & \mathrm{I} & \mathrm{E} & \mathrm{N} & \mathrm{I} & \mathrm{A}\end{array}$

\title{
Mateusz Wyżga
}

ORCID: https://orcid.org/0000-0002-0049-4210

Uniwersytet Pedagogiczny im. Komisji Edukacji Narodowej w Krakowie,

Wydział Humanistyczny

email: mwyzga@up.krakow.pl

\section{Ludzie rodowici i migranci - czy słuszny podział? Wokół książki Jeremy'ego Hayhoe'a Strangers and Neighbours. Rural Migration in Eighteenth-Century Northern Burgundy, Toronto: University of Toronto Press, 2016, ss. 274}

\section{Natives and Migrants - A Correct Categorization? Some Reflections on Jeremy Hayhoe's Book Strangers and Neighbours. Rural Migration in Eighteenth-Century Northern Burgundy, Toronto: University of Toronto Press, 2016, 274 pp.}

\begin{abstract}
Abstrakt
W artykule omówiono książkę poświęconą migracjom wewnętrznym i mikromobilności chłopów w osiemnastowiecznej, północnej Burgundii. Jej autor starał się dowieść znaczenia ruchliwości geograficznej i jej powszechności, głównie za pomocą analizy statystycznej źródeł masowych. Omawiana praca jest przykładem zastosowania metod mieszanych i różnych źródeł. Jeremy Hayhoe oparł swe badania głównie na niewykorzystywanych szerzej zeznaniach świadków zarejestrowanych
\end{abstract}

\begin{abstract}
The paper reviews a book on internal migrations and the micromobility of peasants in $18^{\text {th }}$-century northern Burgundy. Its author set out to demonstrate the significance of geographical mobility and its widespread occurrence, mostly through the statistical analysis of mass sources. The work is an example of the use of mixed methods and diverse sources. Jeremy Hayhoe primarily based his research on the depositions of witnesses in court trials (previously largely unused),
\end{abstract}


w sprawach sądowych, na napoleońskim spisie ludności (1808-1813), rejestrach podatkowych oraz na księgach metrykalnych ślubów. Na podstawie tych źródeł powstała baza około 70000 danych. Badanie objęło egzogamię małżeńską, proporcje ludności miejscowej i napływowej, pokonywane dystanse przestrzenne i roczne wskaźniki migracji. W książce omówiono migracje w podziale na czas ich trwania, czynniki skłaniające do wychodźstwa i przyciągające migrantów, motywacje ludzkie, wreszcie sposoby regulowania napływów ludzi przez społeczności lokalne. Okazało się, że większość mieszkańców osiemnastowiecznych wsi w północnej Burgundii doświadczyła w swym życiu migracji, które miały na ogół podłoże ekonomiczne i przebiegały na krótkich dystansach. Chociaż dominujące były przemieszczenia o charakterze czasowym, odgrywały one ważną rolę $\mathrm{w}$ funkcjonowaniu społeczności lokalnych.

\section{Słowa kluczowe}

północna Burgundia, migracje wewnętrzne, wieś, praca sezonowa, rolnictwo, rzemiosło, pracownicy niewykwalifikowani, dystans geograficzny the Napoleonic Census (1808-1813), tax registers, and marriage records. Based on these sources, a database of 70,000 records was compiled. The research covered marital exogamy, ratios of local to incoming populations, distances covered, and annual migration rates. The book discusses migrations in terms of their duration, pull and push factors, human motivations, and the ways in which local communities tried to regulate the inflows of people. The research indicates that a majority of the population of rural areas in eighteenth-century northern Burgundy experienced migration in their individual lives. This was usually motivated by economic reasons and undertaken over short distances. While movements of a temporary nature were predominant, they played an important role in the functioning of local communities.

\section{Keywords}

northern Burgundy, internal migrations, rural areas, seasonal employment, farming, crafts, unqualified labour, geographical distance

Przez historyków społecznych coraz bardziej doceniana jest rola pomijanych dotąd migracji wewnętrznych, a zwłaszcza mikromobilności (micromobility), czyli ruchliwości w przestrzeni życia codziennego, wpływającej na inne zjawiska demograficzne'. Jeremy Hayhoe skupił się przede wszystkim na doświadczeniu mobilności, a zwłaszcza wpływie migracji krótkodystansowych i czasowych na życie mieszkańców osiemnastowiecznej wsi francuskiej, i sposobach lokalnych społeczności na radzenie sobie z przepływami migracyjnymi. Zasięg terytorialny

\footnotetext{
${ }^{1}$ Ostatnio: Collin G. Pooley, Mobility, Migration and Transport: Historical Perspectives (Lancaster: Palgrave Macmillan, 2017), 28-36; tenże, „Local Histories of Migration and Mobility", Local Population Studies 100 (2018), 1: 52-59.
} 
badań objął część prowincji Burgundia, pokrywający się z powstałym w 1789 roku departamentem Cote-d'Or. Dobrany w ten sposób mikroregion ma zdaniem autora uzupełnić lukę w badaniach między analizą lokalną a narodową (mid-scale work) (s. 3-4) ${ }^{2}$. Badacz twierdzi, że historiografia francuska nie doceniała dotąd roli przemieszczeń wewnętrznych, które uznawano za zbyt krótkie, by mogły odgrywać większą rolę w zmianie społecznej. Tymczasem przekroczenie granicy swej wsi czy parafii było najczęściej doświadczanym zdarzeniem demograficznym w życiu północnych Burgundczyków i wpływało na nie, chociaż nie pozostawiało automatycznie śladu w dokumentacji ${ }^{3}$. Udowodnienie tego wymagało od autora poszukiwania źródeł pośrednich i ich łączenia, jak również zastosowania różnych podejść badawczych. Podstawowym źródłem były nieznane dotąd szerzej protokoły zeznań świadków migrantów, którzy stawili się w 58 sądach ziemskich z obszaru północnej Burgundii w sprawach cywilnych i kryminalnych w latach 1700-1790. Często rejestrowano tam osoby z niższych stanów społecznych. Utworzona na tej podstawie nominatywna baza danych 12847 rekordów pozwoliła zebrać informacje o nazwisku, wieku, zawodzie, zdolności do podpisania się, miejscu urodzenia i zamieszkania. Zasób danych został podzielony na świadków zamieszkujących tę samą osadę co osoba będąca stroną procesu, jak też świadków z innych miejscowości. Informacje o pochodzeniu geograficznym pozwoliły na obliczenie dystansów przestrzennych migracji. Zaletą tego źródła jest występowanie migrantów czasowych, przeważnie nierejestrowanych przez źródła podatkowe, spisy ludności czy księgi metrykalne. Ułomnością zaś jest prawie zupełny brak historii życia migrantów. Problem stanowi również nadreprezentacja chłopów lepiej sytuowanych i osiadłych w lokalnej społeczności, gdyż to takich przeważnie, jako osoby wiarygodne, starano się wybierać na świadków. Ponieważ istniała odwrotnie proporcjonalna zależność między zamożnością a migracją, sam autor zaznaczył, że rezultat badań mógłby przesadnie wskazywać na stacjonarność Burgundczyków. Inny problem, który wszak doskwiera powszechnie badaczom dawnych migracji, to niedobór kobiet, które stanowiły jedynie $25 \%$ ogółu badanej grupy. Trudno było również wykluczyć z bazy wszystkich dublujących się świadków. Tu należy dodać, że J. Hayhoe nie precyzuje dokładnie, jaki typ ludności rozumie przez migrantów wiejskich, najczęściej używając określenia co do charakteru ich osadnictwa. Zasadniczo w tej lekko górzystej krainie

\footnotetext{
2 Podobne obszary do badań wyznaczył Gérard Béaur, „Mobiles et sédentaires? Les familles rurales normandes face au problčme de la migration au XIXe sičcle (Bayeux, 1871-74)”, w: Luigi Lorenzetti, Anne-Lise Head-König, Joseph Goy, red., Marchés, migrations et logiques familiales dans les espaces français, canadien et suisse, 18e-20e siècles (New York: Peter Lang, 2005), 263-277.

${ }^{3} \mathrm{~W}$ tym samym kierunku: Steve Hochstadt, Mobility and Modernity: Migration in Germany, 1820-1989 (Ann Arbor: University of Michigan Press, 1999), 7-8.
} 
ludność wiejska utrzymywała się z rolnictwa, hodowli, upraw winorośli, pracy w lasach oraz rzemiosła i drobnego handlu. Najbliższym większym miastem było Dijon, ale autor świadomie zrezygnował z głębszej analizy ośrodków miejskich z powodu znacznego zaawansowania historiografii w tym zakresie (s. 6-9, 196).

Ponieważ wiele typów ludzkiej ruchliwości wchodzi w pojęcie mobilności, prosty podział analizowanej grupy na osoby rodowite i przybyłe, od którego wychodzą omawiane badania, pomijał grupy migrantów czasowych czy migrantów powrotnych ${ }^{4}$. Autor uzupełnił więc badania o napoleoński spis ludności z roku IV (1796), powstały głównie dla celów porządkowych. Spis ten jest o tyle wyjątkowy, że zawiera informacje o pochodzeniu osób zamieszkujących daną społeczność lokalną krócej niż rok, co pozwoliło na określenie proporcji ludzi napływowych (wraz z datą przybycia) i mieszkańców rodowitych (bez uwzględnienia migrantów powrotnych). Mimo że rejestr napoleoński pozwolił uzyskać wartość rocznej stopy migracji, część spisów musiała zostać odrzucona z powodu ich nierzetelności. Ponadto źródło ogranicza się do osób powyżej 12. roku życia. Dla lepszej wiarygodności badania zostały uzupełnione o akta parlamentu dystryktu Dijon, akta dworskie i gminne, spisy podatkowe i księgi metrykalne z obszaru północnej Burgundii (tu autor wykorzystał bazę udostępnioną mu przez jedno z lokalnych towarzystw genealogicznych). W sumie praca została oparta na około 70000 danych. Kładąc nacisk na migrację czasową, J. Hayhoe nie odniósł się jednak do wykorzystania źródeł o charakterze gospodarczym, np. rejestrów celnych, co mogłoby uchwycić ruchliwość wahadłową ${ }^{5}$ związaną z funkcjonowaniem chłopów w sieciach rynków lokalnych.

W pierwszym rozdziale J. Hayhoe podjął próbę zmierzenia mobilności poprzez egzogamię (tj. małżeństwa, w których mąż i żona urodzili się w różnych społecznościach lokalnych), proporcję rodowitych mieszkańców oraz pokonywane dystanse. Na podstawie źródeł spisowych i sądowych obliczył, że społeczności dorosłych Burgundczyków (powyżej 20. roku życia) w połowie składały się z osób urodzonych $\mathrm{w}$ tej samej osadzie i z osób nierodowitych, czyli przybyszy. Ponieważ jednak egzogamia małżeńska była jedynie fragmentem ogólnej liczby przemieszczeń, i to na mniejsze dystanse niż inne typy migracji, metoda ta wymaga kontekstu porównawczego (s. 23-24). Ze spisu ludności wynikło, że przeprowadzka po ślubie objęła około $15 \%$ ogółu przemieszczeń wewnętrznych

\footnotetext{
${ }^{4}$ Osoby nierodowite to te „chwycone przez źródło” w danym momencie, a rodowici nawiązują do „elementu parafialnego” w badaniach E. Ravensteina - Ernest G. Ravenstein, „The Laws of Migration, Second Paper", Journal of the Royal Statistical Society 52 (1889), 2: 241-305.

${ }^{5} \mathrm{O}$ problemach z uchwyceniem działalności handlowej kobiet zob. Anne Montenach, „Legal Trade and Black Markets: Foodtrades in Lyon in the Late Seventeenth and Early Eighteenth Centuries", w: Female Agency in the Urban Economy: Gender in European Towns, 1640-1830, red. Deborah Simonton, Anne Montenach (New York: Routlege, 2013), 17-33.
} 
w Burgundii, co przypomina wzorce obliczone dla ówczesnej Anglii i Włoch. W zależności od użytego źródła wysokość egzogamii w wybranych 84 wsiach mikroregionu wahała się od $45 \%$ ogółu związków małżeńskich (spis ludności $\mathrm{z}$ roku 1796) do 39\% (księgi metrykalne $\mathrm{z}$ lat 1740-1829). Jedynie co czwarte małżeństwo składało się z miejscowych nupturientów, gdyż w pozostałych przypadkach przynajmniej jeden ze współmałżonków w chwili ślubu mieszkał od pewnego czasu poza swoją rodzinną miejscowością. Według spisu ludności aż 43\% Burgundczyków powyżej 12. roku życia przebywało na migracji czasowej. Roczna stopa migracji matrymonialnej wyniosła 0,035 i była niższa niż u osób nieżonatych (kobiety: 0,065, mężczyźni: 0,093). Trzy razy częściej niż nowożeńcy migrowały pary małżeńskie, w tym posiadające już dzieci. Około połowa takich par osiadłych we wsiach burgundzkich po kilku latach znów zmieniała swoje miejsce zamieszkania. Okazało się, że 2/3 migrujących par Burgundczyków to rolnicy zamożni, których stać było na przeprowadzkę całej rodziny w związku z dzierżawą czy zakupem kolejnego gospodarstwa. Uboższe małżeństwa częściej przemieszczały się same, gdyż ich potomstwo było już wtedy rozdysponowane, np. w służbie domowej. Po ślubie kobiety częściej migrowały do wsi swego współmałżonka niż na odwrót, ale różnica nie była znacząca (56 do 44\%), co może się wiązać z istniejącą w północnej Burgundii równością płci wobec dziedziczenia (s. 18-20).

W dalszej kolejności J. Hayhoe zbadał mobilność i egzogamię małżeńską w odniesieniu do zawodu wykonywanego przez migrantów. Nie zastosował tu jednak kategoryzacji HISCO/HISCLASS, a jedynie ogólny podział rzemiosł. Wyjaśnił, że opieranie się na kategoryzacji zawodowej może być problematyczne, gdyż profesje zmieniano w zależności od bieżącej sytuacji i cyklu życia. Są też mało przydatne w badaniu ludzi młodych, a także kobiet. Wiadomo, że rzemieślnicy wiejscy, zwłaszcza chodzi tu o zawody związane z produkcją żywności i odzieży, stanowili podobną proporcję wśród burgundzkich migrantów co rolnicy (około 45\%). Trudno bliżej scharakteryzować branżę leśną i budowlaną, gdyż wielu pracowników masowo przemieszczało się zarówno przed, jak i po ślubie. Następnie J. Hayhoe uznał, że badanie egzogamii w podziale na wiek i zawód przeszacowuje mobilność bogatych chłopów wobec niedoboru wiadomości o pozarolniczej elicie wiejskiej, o wywodzących się w większości spoza osady biedniejszych rolnikach, a także zatrudnianych przez właścicieli ziemskich i społeczności wiejskie robotnikach - służbie domowej, pasterzach, strażnikach leśnych czy ogrodnikach wynajmowanych do opieki nad plantacjami warzywnymi (za co później mogli sprzedać część plonów na własny rachunek). $Z$ tej przyczyny nawet w poszczególnych osadach w jednej okolicy mogły mieć miejsce rozbieżne wskaźniki mobilności i egzogamii (w tym drugim przypadku różnica sięgała $18-72 \%$, a w przypadku proporcji osób nierodowitych 25-75\%). Egzogamia nie 
pomogła wyjaśnić proporcji osób nierodowitych, gdyż niekiedy młodzi ludzie z mniejszych osad byli zmuszeni szukać współmałżonka poza swoją wsią (s. 2022).

Następnie zostały zbadane pokonywane przez ludzi dystanse geograficzne. Porównano pochodzenie małżonków z 1348 związków egzogamicznych oraz 653 „nierodowitych” świadków sądowych. Egzogamia miała miejsce na krótszych dystansach niż inne typy mobilności, gdyż odległość nie sprzyjała zdobyciu zaufania przyszłego małżonka, a zwłaszcza jego rodziny i społeczności, do której się wżeniano. Małżeństwo zawarte w danej wsi nie oznaczało, że para tam zamieszkiwała. Jak już podano, chłopi burgundzcy częściej żenili się w parafii rodziców pani młodej. Co do ożenków we wsi kawalera autor przypuszcza, że takie kobiety migrantki mieszkały tam już od pewnego czasu, jednak księgi ślubów nie zawierają informacji o ich „historii rezydencjonowania”. Około 80\% nupturientek i 50\% nupturientów urodziło się w miejscowości, gdzie później miał miejsce ich ślub. Hayhoe nie podaje tutaj jednak szczegółów jeżeli chodzi o związki powtórne i wpływ wdowieństwa na egzogamię (s. 50-51, 200). Z ksiąg sądowych wynikło natomiast, że proporcje płci migrantów były dość wyrównane. Również dystanse matrymonialne były podobne dla obu płci, chociaż kobiety rzadziej przemieszczały się na dalsze odległości. Osada Serrigny była wyjątkowa pod tym względem, że kobiety migrantki wywodziły się z dalszych osad (mediana $19 \mathrm{~km}$ ) niż mężczyźni $(13 \mathrm{~km})$. J. Hayhoe wnioskuje, że wynikało to z faktu, że większość miejscowych mężczyzn szukała partnerki wśród rodowitych mieszkanek, co sztucznie wyolbrzymiało dystanse pokonywane przez obce kobiety. Średni dystans geograficzny partnerów egzogamicznych w północnej Burgundii wyniósł $30 \mathrm{~km}$ (mediana: $11 \mathrm{~km}$ ), podczas gdy nierodowici świadkowie sądowi pokonywali $43 \mathrm{~km}$ (mediana $16 \mathrm{~km}$ ). Wynika z tego, że przemieszczenia niezwiązane z mariażem były nieco dłuższe niż migracja małżeńska. Ta wymagała lepszego poznania partnera i regularnych kontaktów. Dla porównania przemieszczenia o podłożu ekonomicznym wymagały głównie dostępu do informacji o możliwościach zatrudnienia i noclegu. Zasięg geografii małżeńskiej odzwierciedla w zasadzie obszar cyrkulacji ludzi niższych stanów społecznych w znanej im doskonale przestrzeni życia codziennego. Cenny to wniosek dla badań ograniczonych do ksiąg metrykalnych, gdyż można domniemywać, że zasięg doboru małżonka odbija w przybliżeniu właśnie przestrzeń geograficzną życia codziennego.

Jeremy Hayhoe użył dwóch sposobów mierzenia dystansów przestrzennych: pieszego przejścia wzdłuż najkrótszych, istniejących dróg oraz w linii prostej. Po wprowadzeniu do programu Ms Excel współrzędnych geograficznych obliczył odległości od miejsca urodzenia do miejsca zamieszkiwanego przez migrantów, w momencie kiedy zostali zarejestrowani w źródle. Jednocześnie pomiary odcinków pośrednich (migracji czasowych i etapowych) odrzucił z badania ze 
względu na pracochłonność ich zestawiania i niedokładność w oddawaniu wielkości przemieszczeń w cyklu życia człowieka. Autor zakwestionował tezę Ernesta Ravensteina, że to kobiety częściej niż mężczyźni opuszczały wieś urodzenia, ale migrowały na bliższe dystanse. Chociaż żyło ich mniej w parafii, w której się urodziły, to obie płci w równym udziale migrowały poza dobrze znany obszar życia codziennego. Zasięg świata familiarnego, tj. obszaru, w którym przebiegała większość życia chłopów burgundzkich, Hayhoe określił na około $15 \mathrm{~km}$ (mediana) w najkrótszym przebiegu drogowym. Licząc tym sposobem, doszedł do wniosku, że osoby napływowe mieszkały średnio $38 \mathrm{~km}$ od wsi, gdzie je zarejestrowano jako czasowych mieszkańców (mediana: $13 \mathrm{~km}$ ), zaś w linii prostej $28 \mathrm{~km}$ (mediana: $10 \mathrm{~km}$ ).

W zeznaniach sądowych dotyczących chłopów burgundzkich uczestniczyło wielu mieszczan. Łączyły ich liczne więzi społeczno-gospodarcze. Według autora małe miasta i wsie na analizowanym terenie miały zbliżone proporcje migrantów, tj. co druga osoba nie urodziła się w miejscowości pobytu. Równocześnie zasięg rekrutacji migrantów do miast był nieco szerszy niż na wsiach, gdyż dla poszczególnych ośrodków mediana wyniosła 20-37 km. Jednak co trzeci przybysz wywodził się ze wsi odległej nie więcej jak $15 \mathrm{~km}$, a więc ze strefy żywicielskiej miasta. Wątek migracji wiejsko-miejskich, zwłaszcza w kontekście działania rynku lokalnego, nie został jednak bardziej rozwinięty. Wiadomo jedynie, że rynki miejskie na omawianym obszarze pokrywały około $220 \mathrm{~km}^{2}$, a średni dystans oddzielający chłopów w linii prostej od targu wynosił $8 \mathrm{~km}$ (s. 25-26, 72-76).

Wykonywany zawód wpływał na mobilność i zasięg przemieszczeń. Rolnicy byli relatywnie najmniej mobilni, zwłaszcza osoby płci męskiej. Mężczyźni byli płcią uprzywilejowaną w kwestii dziedziczenia gospodarstw, skoro w przypadku $66 \%$ małżeństw egzogamicznych to żony migrantki osiadały u nich. Natomiast winiarze mieli odmienne wzorce mobilności na poszczególnych obszarach, przy czym wyższa zamożność wpływała na większą zdolność do migracji. Podobnie jak w ówczesnej Fryzji, napływowi mieszkańcy wsi przeważali wśród zawodów nierolniczych, głównie rzemieślników. Przenikali też na dalsze odległości, chociaż ich żony nie były już tak mobilne ${ }^{6}$.

Najczęstszą formą przemieszczeń mieszkańców Europy wczesnonowożytnej była mikromobilność, a więc pokonywanie stosunkowo krótkich dystansów. Około połowa Burgundczyków mieszkała we wsi, w której się urodziła, ale 75\% z nich w trakcie swego życia doświadczyło pobytu poza rodzinną osadą, zwykle na dystansie do $15 \mathrm{~km}$. Jednak już co czwarty migrant przekraczał obszar codziennej

\footnotetext{
${ }^{6}$ Por. Anne McCants, „Internal Migration in Friesland, 1750-1805”, Journal of Interdisciplinary History 22 (1992): 403-404.
} 
cyrkulacji i praktycznie w każdej wsi żyło kilkoro ludzi spoza mikroregionu, będących nośnikami wiedzy o szerszym świecie. Niektórzy z nich urodzili się przeszło $100 \mathrm{~km}$ dalej. W pewnym sensie świadczy to o otwartości lokalnych społeczności na wpływy zewnętrzne (s. 29). Analiza migracji przekraczających granice lokalne $\mathrm{w}$ połączeniu $\mathrm{z}$ grupami zawodowymi przyniosła nadreprezentację mężczyzn, zwłaszcza robotników sezonowych, takich jak kamieniarze czy tracze. Zarejestrowani w poszczególnych sądach okręgowych migranci, którzy zamieszkiwali na stałe w odległości powyżej $50 \mathrm{~km}$ od miejsca pochodzenia, stanowili $25-60 \%$ świadków. Wysoki udział w dalekich migracjach należał do rzemieślników, z których ponad połowa przybyła z odległości większej niż $15 \mathrm{~km}$, a co trzeci pokonał nie mniej jak $50 \mathrm{~km}$. Były to zawody związane z produkcją żywności (piekarze, rzeźnicy), a także kowale, tkacze i specjaliści od obróbki skór (garbarze, szewcy). Ich wędrówka była powiązana z praktyką zawodową. Wiadomo, że przy dobieraniu kierunku wędrówki wspierali się oni informacjami o zwalniających się miejscach pracy w ich profesji, np. cieśle zmierzali ku bardziej zalesionym terenom. W przypadku służby domowej wysoki poziom osób nierodowitych nie oznaczał aż tak długich dystansów, gdyż tylko co piąty służący przeszedł ponad $50 \mathrm{~km}$, podobnie jak rolnicy. Większość gospodarzy samowystarczalnych nie migrowała na więcej jak $15 \mathrm{~km}$, a odległość 50-100 km pokonał tylko co dziesiąty mężczyzna, rzadziej kobieta. Mniejsze dystanse podejmowali ubożsi i bezrolni chłopi, chociaż i tak prawie połowa z nich (w przypadku obu płci) przekroczyła zasięg $15 \mathrm{~km}$ (s. 31-34).

Analiza wzorców mobilności w długim trwaniu na podstawie kilku tysięcy rekordów ze spisów ludności z lat 1796 i 1872 pozwoliła autorowi recenzowanej pracy nawiązać do toczącej się polemiki odnośnie do koncepcji tzw. przejścia mobilności, czyli związku między poziomem ruchliwości terytorialnej a modernizacją (s. 34-37). Wzorce mobilności, zasięg pokonywanych dystansów i udział mieszkańców nierodowitych pozostawały na podobnym poziomie w obu stuleciach, a dziewiętnastowieczne wsie charakteryzowały się stopniowym spadkiem liczby urodzeń, na co nałożyła się rosnąca atrakcyjność miast i miasteczek. Proporcje nierodowitych mieszkańców (w wieku powyżej 20 lat) w stosunku do rodowitych pozostały na około pięćdziesięcioprocentowym poziomie. Nie zmienił się również zasięg geograficzny przemieszczeń, co J. Hayhoe uznał za przejaw stabilności „basenu naboru” migrantów na omawianym obszarze. Zjawisko migracji dotyczyło głównie uboższych warstw społeczności wiejskiej (zwłaszcza młodzieży), liczniej odpływających do dynamicznie rozwijających się miast, a kiedy osłabła siła przyciągania wsi, zanikały też przemieszczenia sezonowe. Pozostali w swych osadach ludzie byli mocniej związani ze swymi społecznościami lokalnymi, ale jednocześnie w mniejszym stopniu mobilni, przedsiębiorczy i skłonni do ryzyka. Mimo tego egzogamia, przez którą miejscowe wsie były 
zasilane obcymi ludźmi, pozostała na podobnym poziomie około 64\% ogółu małżeństw, a nupturienci poznawali się w obrębie około $30 \mathrm{~km}$ (mediana: $11 \mathrm{~km}$ ). Ogółem pokonywane przez Burgundczyków dystanse utrzymały się w obu stuleciach na średnim poziomie $35 \mathrm{~km}$ (mediana 10). Nie uległa zmianie także roczna stopa migracji (s. 36-41).

Wykonywana na wsi profesja miała związek z prawdopodobieństwem zamieszkania $\mathrm{w}$ osadzie urodzenia, $\mathrm{z}$ migracją i długością pobytu $\mathrm{w}$ danym miejscu. Na dłużej osiadali migranci będący zamożnymi chłopami (oracze, ploughmen). Częstotliwość ich trwałych przemieszczeń ograniczana była trudnościami z wynajęciem lub zakupem dostatecznej do utrzymania się wielkości działki rolnej. Problemy takie mogły stwarzać migrantom społeczności lokalne w trosce o własne zasoby produkcyjne. Chłopi ci migrowali również na krótsze dystanse niż przedstawiciele innych zawodów. Trudno jednak uznać ich za typ osiadły ludności, gdyż w razie problemów ze znalezieniem właściwego gospodarstwa lub kłopotów finansowych mogli sprzedać woły i konie, przechodząc do warstwy zagrodników (cottagers). W przypadku rzemieślników niezwiązanych z rolnictwem, jak np. piekarze czy rzeźnicy, o 10\% wzrastało prawdopodobieństwo, że będą żyć poza wsią, w której się urodzili. Wiadomo też, że zamożniejsi rolnicy i winiarze zwykle byli mniej mobilni niż ich żony, co mogło częściowo wynikać z lokalnej praktyki dziedziczenia gospodarstwa. Z kolei żony rzemieślników pokonywały mniejsze odległości, gdyż to ich mężowie dłużej przebywali w drodze w poszukiwaniu miejsca zdatnego do założenia rodziny. Aż $75 \%$ młodych rolników żyło na obszarze jednodniowego marszu od miejsca urodzenia, a połowa całej młodzieży wiejskiej żyła poza miejscem urodzenia.

Dane oparte na spisie ludności nie ujmują pełnej historii wędrówek człowieka pomiędzy urodzeniem się a miejscem aktualnego zamieszkania. Nieostrożne użycie „stabilnych” punktów życia jednostki może wpłynąć na niedoszacowanie ogólnej mobilności, stąd też autor uzupełnił badania przez określenie ryzyka jednostki do przemieszczenia się w trakcie roku. Ponieważ jednak spisy ludności z sąsiednich lat nie były dostępne, J. Hayhoe połączył dostępne źródła nominatywne spisowe i sądowe, co uzupełnił o studium przypadku społeczności wiejskiej osady Corgengoux. Wynikło z tego, że z grona 14750 zarejestrowanych w 1796 roku mieszkańców wybranych do analizy wsi jedna na 20 dorosłych osób zmieniła w poprzednim roku miejsce zamieszkania, a roczne ryzyko migracji wyniosło 0,052 (wartość wzrosłaby po doliczeniu migracji powrotnych do 0,06). Migracja powrotna była dość powszechnym zjawiskiem w przednowoczesnej Europie. Wiadomo na przykład, że tylko 15-20\% siedemnastowiecznych Anglików mieszkało w miejscu urodzenia, ale i tak doświadczyli oni w swym życiu przynajmniej dwukrotnej zmiany miejsca zamieszkania. Podobnie co piąte przemieszczenie pod dziewiętnastowieczną Genewą było migracją powrotną 
(s. 41-43) ${ }^{7}$. W powyższy sposób nie udało się jednak autorowi recenzowanej pracy uchwycić ludzi w stałym ruchu, jak np. czeladników rzemiosła, rekrutów i robotników dniówkowych.

Większa skłonność do migracji wynikała z miejsca jednostki w cyklu życia (ludzie młodzi i bezżenni). Podobnie jak w innych częściach Europy, migracje w północnej Burgundii najczęściej nie były stałe. Migranci nie pozostawali w jednym miejscu na długi czas, skoro $40 \%$ z nich opuściło badany obszar w trakcie roku, a tylko 33\% mieszkało tam dłużej niż 5 lat. Społeczności wiejskie mogły zatem oczekiwać, że połowa przybyłych do ich osady osób opuści je w ciągu kilku następnych lat, co musiało wpływać na ograniczone zaufanie do przybyszy. Nieliczni żyjący dłużej niż 5 lat w nowej osadzie (w większości kobiety) stanowili grupę malejącą np. z powodu umieralności. W przypadku obu płci odpływ migrantów był wysoki przez pierwsze dwa lata od przybycia, a potem stopniowo spadał. Ludzie młodsi byli bardziej skłonni do migracji czasowych niż starsi, a najważniejszym wskaźnikiem dla długości pobytu okazał się stan cywilny. Przykładowo kobiety zamężne (bez wdów) stanowiły około 80\% ogółu kobiet pozostających na dłuższy czas, z których połowa była migrantkami. Stąd ryzyko corocznej migracji w przypadku kobiet zamężnych wynosiło 0,043 , a w przypadku ogółu kobiet półtora raza więcej $(0,065)$. U mężczyzn różnica pod względem stanu cywilnego była jeszcze wyższa $(0,035-0,093)$ (s. 42-44).

Z kolei mężczyźni i kobiety w trzeciej dekadzie życia mieli trzykrotnie większą szansę na migrację niż czterdziesto- czy pięćdziesięciolatkowie. W dwudziestych latach swego życia większość służby domowej wchodziła w związki małżeńskie, zostając początkowo ubogimi rolnikami lub robotnikami dniówkowymi. W późniejszym wieku ryzyko migracji stopniowo spadało, by nieco wzrosnąć po 70. roku życia, kiedy starcy przenosili się do swych dzieci lub gdzie indziej, w zależności od ustaleń osobistych, a wskaźniki ich mobilności wyglądały podobnie jak u osób w czwartej i piątej dekadzie życia. Starzenie się nie miało więc oczywistego przełożenia na osiadłość. Wiadomo, że migracji podejmowali się również robotnicy dniówkowi obojga płci liczący więcej niż 60 lat. Połowa z nich migrowała ze współmałżonkiem lub za dziećmi i wnukami do wsi, w której te zawarły małżeństwo. Niektórzy przechodzili na utrzymanie potomstwa, chociaż należy wziąć pod uwagę tendencję wdowców do ponownych ożenków i niechęć dzieci/wnuków do przejmowania opieki nad starszymi, zwłaszcza jeżeli były przyzwyczajone do samodzielnego sterowania gospodarstwem. Więcej kobiet niż mężczyzn rezydowało poza miejscem urodzenia, ale to mężczyźni, bez względu na wiek, przemieszczali się częściej (s. 46-49).

${ }^{7}$ Peter Clark, David Souden, wstęp do: Peter Clark, David Souden, red., Migration and Society in Early Modern England (London: Hutchinson, 1987), 29-34. 
Jeremy Hayhoe skorelował następnie proporcję osób nierodowitych z roczną stopą migracji dla 84 wsi w 1796 roku, a wynik okazał się podobny $(0,435-0,495)$ i potwierdził, że mniej mobilni niż ludzie stanu wolnego i służba domowa byli gospodarze pełnorolni i małżeństwa, a migranci krótkoterminowi byli relatywnie starsi niż długoterminowi. Tym niemniej każdy człowiek, bez względu na wiek, płeć, stan społeczny i zawód miał szansę na migrację - na przykład 40\% świadków w sądach deklarujących zamieszkanie w danej miejscowości zmarło gdzie indziej, a w grupie osób żyjących w danej wsi od urodzenia do chwili rejestracji co trzeci miał w swym życiu jeszcze się przenieść do innej osady i tam umrzeć. Wśród 196 świadków sądowych z osady Corgengoux 47\% urodziło się w innej miejscowości, oddalonej średnio o $26 \mathrm{~km}$ (mediana: $10 \mathrm{~km}$ ). Wywodzili się oni z około 50 okolicznych wsi, reprezentując w zasadzie wszystkie społeczności lokalne na analizowanym obszarze. Przy połączeniu danych z ksiąg metrykalnych i spisu podatkowego okazało się, że w ciągu 73 lat połowa podatników urodziła się poza Corgengoux i była tylko nieco uboższa niż rodowici mieszkańcy. Przeciętnie człowiek taki płacił podatek tylko 7 i pół roku, po czym znikał z pola obserwacji, a połowa podatników mieszkała tam nie dłużej niż 5 lat. Poszukiwania tych ludzi w księgach chrztów miejscowej parafii pokazały, że jedynie $17 \%$ urodzonych tam mężczyzn pozostało w Corgengoux. Po dodaniu do tej liczby rodowitych mieszkańców żyjących czasowo gdzie indziej, było to zaledwie około $29 \%$ rodowitych osób. Jak już podano, ludzi osiadłych cechowała głównie zamożność, posiadanie nieruchomości, ale umierali stosunkowo młodo (średnia: 44 lata) i gdyby żyli dłużej, ich szansa na migrację uległaby zwiększeniu ${ }^{8}$. Zasadniczo $\mathrm{w}$ analizowanej wiosce corocznie przybywała i ubywała jedna osoba wśród płatników podatku. Mniejszość, która osiadła w związku z małżeństwem, pozostała w Corgengoux do śmierci, a inni ruszyli dalej (s. 51-55).

W dalszej kolejności J. Hayhoe przekonuje, że chłopi francuscy byli nie mniej mobilni niż w sąsiednich krajach. Kontestuje w ten sposób wnioski Petera Lasletta oparte na porównaniu ruchliwości przestrzennej gospodarstw domowych w kilku mikrospołecznościach Anglii i Francji. W tym celu J. Hayhoe zestawił proporcje osób nierodowitych, wskaźniki migracji i pokonywane dystanse w Europie zachodniej. Najpowszechniejszy wskaźnik w badaniach tego typu to proporcja osób nierodowitych, która w różnych częściach kontynentu wynosiła $35-65 \%$ mieszkańców. Podobne były też salda migracji, gdyż co roku 4-6\% ludzi zmieniało miejsce pobytu. Jeżeli chodzi o geografię migracji, dystanse pokonywane przez Burgundczyków były podobne do znanych z Anglii, Holandii, Szkocji czy Szwecji tego czasu. Najniższe wskaźniki miały miejsce w południowej

\footnotetext{
${ }^{8}$ Udowodnił to Steven Ruggles - „Migration, Marriage, and Mortality: Correcting Sources of Bias in English Family Reconstitutions," Population Studies 46 (1992), 3.
} 
Francji, gdzie dominowała primogenitura i rodziny o charakterze złożonym. Społeczności te były bardziej zamknięte na obcych, ale mogły mieć wysoki wskaźnik emigracji; osady te Fernand Braudel nazywał „fabryką produkującą ludzi dla użytku innych". Średnią liczbę przemieszczeń zwiększały migracje do miast, ale J. Hayhoe nie rozwija tego wątku (s. 59-63). Autor przekonuje po raz kolejny, że ludzie doświadczali tak wielu różnych migracji, że dzielenie ich na mobilnych i osiadłych jest nietrafne; używa nawet nie tyle określeń rodowici czy mieszkający od pokoleń i na stałe, ile mieszkańcy długoterminowi (long-term residents). Osiadłość na całe życie w północnej Burgundii była rzadkością. Chociaż ludzie przenosili się w naszym pojęciu na stosunkowo niewielkie dystanse, gdyż połowa migrantów zamieszkała nie dalej jak $15 \mathrm{~km}$ od miejsca urodzenia, jednak odległości wówczas i dziś nie można porównywać, jeżeli weźmiemy pod uwagę zaawansowanie techniki i zasięg relacji gospodarczych, społecznych i rodzinnych.

W trzecim rozdziale J. Hayhoe ukazał, w jaki sposób mieszkańcy przemieszczali się poza obszar życia codziennego. Dokonał tego na podstawie sądowych pozwów, śledztw i aukcji nieruchomości. Chociaż analiza tych źródeł daje niedobór danych o wiejskiej biedocie, a nadreprezentację kupców i gospodarzy, można się dowiedzieć, z jakich powodów ludzie się przemieszczali i jak działały ich więzi społeczne. Ponad połowa mieszkańców napływowych straciła wszystkie kontakty z poprzednim miejscem zamieszkania i w nowym miejscu pobytu musiała odtworzyć ekonomiczne i społeczne sieci. Chociaż, migrując poza obszar życia codziennego, chłopi pozostawali w jednym obszarze kultury, jednak każda kolejna przekroczona granica wsi niosła za sobą pewne wykorzenienie (s. 79). Tym niemniej życie codzienne nigdy nie było ograniczone jedynie do wsi zamieszkania, a każdy człowiek bez względu na płeć był związany z najbliższą okolicą. Osiemnastowieczni mieszkańcy wsi burgundzkich zwykle podróżowali pieszo w obrębie kilku kilometrów i najczęściej w związku z pracą. Przykładowo rolnicy posiadali działki rozrzucone na dystansie do około $5 \mathrm{~km}$ od domu, co wymuszało codzienną cyrkulację, ale transakcje podejmowali na większym dystansie. W tym względzie zasięg codzienności obliczony na podstawie egzogamii i pochodzenia świadków sądowych był zbliżony. Podróże na dalsze dystanse były konieczne w związku z życiem gospodarczym i ze sprawami do załatwienia w administracji terenowej. Na podstawie około 2000 procesów w 14 sądach okręgowych z piątej i ósmej dekady XVIII wieku okazało się, że jedynie 39\% spraw toczyło się między ludźmi z tej samej wsi. Jednocześnie około $10 \mathrm{~km}$ dzieliło ludzi wywodzących się z różnych osad. Chociaż w materiale źródłowym zwracały uwagę negatywne opinie mieszkańców o przybyszach (np. o ich domniemanej przestępczej przeszłości), aż 85\% drobniejszych spraw (głównie kradzieże, pobicia, obraza) toczyło się między mieszkańcami tej samej osady. Najczęstszą przyczyną konfliktów wśród wieśniaków były sprawy związane z rolnictwem 
i użytkowaniem wspólnych areałów. Wynika z tego, że bliższe współistnienie w większym stopniu było przyczyną braku sympatii, zazdrości czy pogardy niż problem migrantów. Niesnaski ze względu na różne pochodzenie najczęściej wybuchały między grupami młodzieży przybywającymi do okresowej pracy, gdzie w grę wchodził „patriotyzm” lokalny. Jednocześnie zawierane w sądzie umowy kredytu w przypadku interesantów mieszkających w pobliżu powołanych świadków opierały się na umowach ustnych. Wynikało to zapewne z poczucia, że osoby z bliższego otoczenia, z którymi następowały częste kontakty, były bardziej wiarygodne. Przy wierzycielach i dłużnikach mieszkających w większej odległości stosowano częściej pisemne formy kontraktów (s. 13, 65-68).

Według autora większość załatwianych w sądzie spraw wymagała kontaktów międzywiejskich. Chłopi nie byli samowystarczalni, ale mogli zaspokoić swe potrzeby na dystansie około $10 \mathrm{~km}$. Ta sama odległość dotyczyła sporów rzemieślników wiejskich z ich klientami, negocjacji gospodarzy ze służbą domową i pracownikami sezonowymi (żniwiarze, młocarze) o wynagrodzenia (najemnicy część wynagrodzenia dostawali w formie zamieszkania, żywności i odzienia, a resztę, poza zaliczką, na ukończenie kontraktu). Co ciekawe, zamożniejsi rolnicy najczęściej pozywali ludzi z własnej wsi, dalej sięgały interesy winiarzy czy lokalnych kupców. Rozszerzanie się zasięgu kontaktów chłopów w ciągu badanego okresu autor wiąże z poprawą sieci drogowej oraz wpływem „rewolucji konsumenckiej”. Podobne zjawisko przestrzenne dostrzegł w egzogamii, gdzie aż 70\% takich małżeństw dobierało się na dystansie do $10 \mathrm{~km}$ (s. 70).

Do regularnego pokonywania największych dystansów skłonni byli zwłaszcza zamożni rolnicy, których sieci społeczne rozciągały się w całym omawianym mikroregionie, jak też winiarze, podróżujący na rozrzucone szeroko plantacje winorośli, sprzedający tam swe zbiory i zakupujący żywność. Zamożni wieśniacy byli przyzwyczajeni do stałych przemieszczeń, jednak nie odbijało się to w trwalszych migracjach, jak miało to miejsce wśród skupionych na przetrwaniu, a nie polepszeniu standardu życia, uboższych ludzi.

Najczęstszym powodem codziennych, niedalekich podróży ludzi obu płci były kwestie ekonomiczne - poszukiwanie pracy, sprzedaż, kupno czy dostarczenie dóbr. Rzadziej były to sprawy związane z praktykami religijnymi czy życiem towarzyskim, np. festyny wiejskie, gdzie młodzież mogła spotkać potencjalnego przyszłego małżonka. Chłopi podróżowali w celu dokonywania zakupów i najmowania usług potrzebnych $\mathrm{w}$ życiu codziennym, opieki weterynaryjnej nad zwierzętami, wizyt u kowala, a także poszukiwali porad prawnych. Słabiej udokumentowano w źródłach podróże związane z życiem rodzinnym, jak przygodne odwiedziny i ceremonie ślubne czy chrzty. Wizyty u bliskich niekiedy łączyły się z noclegiem i dłuższym pobytem. Pozostawiano też własne dzieci u rodziny na kilka tygodni i mogło tu chodzić o przysposobienie do służby. Mogła to 
być także kwestia pilnowania gospodarstwa krewnego pod jego nieobecność, np. w czasie pobytu w mieście, na zarobku sezonowym. Świadkowie zeznający w sądach byli wynagradzani za poświęcony czas i za dojazd wynajętą furmanką, jeżeli nie byli w stanie przebyć dystansu pieszo, np. ze względu na stan zdrowia. Zarówno kobiety, jak mężczyźni potrafili samotnie przemierzać nawet kilkudziesięciokilometrowe odległości, pytając przygodne osoby o dalszą drogę i możliwość noclegu. O ile było to możliwe, dla bezpieczeństwa preferowano podróż w większej grupie. W wędrówkach ważną rolę odgrywały karczmy, obecne prawie w każdej osadzie, które były centralnymi instytucjami życia towarzyskiego, miejscami socjalizacji, finalizacji interesów czy zatrudnienia9. Skupiały one miejscowych, jak i przybyszy. Aż 3/4 osób wymienionych w sprawach sądowych przesiadywała w obcej karczmie. Przeważnie wywodziły się one z okolicznych wsi, gdyż mediana odległości wyniosła $8 \mathrm{~km}$. Wiadomo także, że wśród osób $\mathrm{z}$ dalszych stron zatrzymujących się w zajazdach byli migranci poszukujący pracy. Odległość powyżej $40 \mathrm{~km}$ pokonywali ludzie związani głównie $\mathrm{z}$ handlem i rzemiosłem, nie było już w tej grupie rolników. Bywalcy karczem liczyli średnio 30 lat. Byli to przeważnie żonaci mężczyźni podróżujący samotnie, z inną osobą żonatą lub ze służącym. Częściej niż okoliczna ludność posiadali oni umiejętność podpisania się. Brak informacji o podróżach par i rodzin może oznaczać, że przemieszczali się z własnym wyżywieniem lub zatrzymywali w domostwach krewniaków i znajomych.

Do ustalenia przestrzeni życia codziennego chłopów burgundzkich przydały się nominacje opiekunów dla sierot, wśród których prócz rodziny pojawiali się przyjaciele domu. Zasięg takich powiązań przekraczał granice wsi i sięgał $10 \mathrm{~km}$. Podobne wzorce przestrzenne odnośnie do cyrkulacji i podróżowania dała analiza osób stawiających się na aukcjach nieruchomości i wyprzedaży sprzętu domowego, jak również dystanse zamieszkania dzielące uczestników bójek toczonych w zajazdach i na festynach (s. 72-76).

W analizie blisko 12000 zeznań świadków sądowych nie pojawiły się informacje o tak potocznej kwestii, jak dotarcie na przesłuchanie. Wiadomo, że średni dystans dzielący ich od urzędu wynosił $10 \mathrm{~km}$ (mediana) i musiał zajmować cały dzień, a z racji praktyki procesowej należało się stawiać więcej niż raz. W tym wypadku ważną grupą mobilnych wieśniaków byli urzędnicy wiejscy obierani corocznie z grona zamożnych gospodarzy przez społeczności lokalne. Byli oni odpowiedzialni za zbiórkę i odstawienie podatku, pilnowanie pól i lasów, obliczanie strat gospodarczych, załatwianie spraw gromady w sądach, dostarczanie

${ }^{9}$ Zob. Beat Kümin, „Public Houses and Their Patrons in Early Modern Europe”, w: The World of the Tavern: Public Houses in Early Modern Europe, red. Beat Kümin, B. Ann Tlusty (Aldershot, UK: Ashgate, 2002). 
młodych mężczyzn na losowanie słomką w celu werbunku do milicji prowincjonalnej. Inne wymagające niekiedy dalszej podróży sprawy to ustalanie nowego plebana u biskupa w siedzibie diecezji, zamówienie krzyża przydrożnego czy zlecenie renowacji zegara wiejskiego. Osoby takie przynajmniej raz w miesiącu musiały się wybierać poza wieś w poruczonych sprawach (s. 77-78).

Jeremy Hayhoe przedstawił następnie przyczyny przemieszczeń ludzkich, a podstawą analizy były dane społecznozawodowe i umiejętność podpisywania się migrantów. Analiza objęła migrantów czasowych i sezonowych, nieosiągających statusu mieszkańca wsi, oraz ich doświadczenia w kontaktach z miejscową ludnością. Każda osada corocznie przyjmowała pracowników sezonowych, a jednocześnie wielu spośród jej osiadłych mieszkańców również podejmowało taką migrację. Za rezydentów wsi uznawano tę niewielką grupę, która płaciła podatki i albo mieszkała całe życie w tej samej osadzie, albo były to osoby osiedlone w wyniku małżeństwa z miejscową osobą, a także zamieszkałe w związku z zawarciem okresowego kontraktu na dzierżawę gospodarstwa. Jednak większość migrantów pojawiała się i odchodziła na mniej pewnej podstawie, trudno ich właściwie policzyć, chociaż pojawiają się licznie w różnych rejestrach. Nie mieli oni dostępu do spraw wsi i pełnego korzystania $\mathrm{z}$ ich dóbr.

Sezonowa migracja pracownicza miała charakter długodystansowy i była powszechnym zjawiskiem w Europie wczesnonowożytnej. Co roku wielu młodych mężczyzn wychodziło na kilka miesięcy szukać pracy, opuszczali oni zwłaszcza mniej urodzajne obszary górskie i napływali do dolin. Właściwym źródłem dla opisania tych procesów był znany już historykom migracji rejestr przepływu robotników sporządzony z nakazu Napoleona w latach 1808-1813. Z analizy wynikło, że 1/4 młodzieży męskiej opuszczała zimą obszary górskie w poszukiwaniu pracy jako tracze, murarze i kamieniarze. Popularnym kierunkiem był Paryż i jego okolice. Latem ludzie ci uprawiali swe niewielkie działki w górach. J. Hayhoe odnalazł takich migrantów wśród świadków sądowych w północnej Burgundii. Nie wszyscy sezonowi pracownicy regularnie i co roku powracali do siebie, chcąc np. uzbierać więcej pieniędzy. Co ciekawe, po zejściu z gór grupy migrantów osiedlały się w jednym miejscu na określony czas aż do powrotu do domu. Dopiero z tej ,stacji” wyruszały w poszukiwaniu pracy w okolicy, na dystansie do kilku kilometrów. Robotnicy wywodzący się z tej samej okolicy działali we własnych sieciach migracyjnych. Migranci tacy byli dość młodzi (średnia to 33 lata), ale i zdarzały się również osoby liczące ponad pięćdziesiąt lat. Najwięcej migrantów było zatrudnianych przy obróbce drewna (tracze) i murarstwie. Byli to także domokrążcy np. handlarze serem. Kramarze ci najpierw rozpoznawali okolicę, w której dystrybuowali towar, a po utworzeniu sieci społecznej osiadali w okolicy na dłużej. Jednocześnie zajmowali się pośrednictwem dla pracowników sezonowych napływających z ich rodzinnych stron. Autor zaznaczył, że przedstawiciele 
innych zawodów przebywali na omawianym terenie na tyle krótko, że nie dało się uchwycić ich w analizie. Wiadomo, że byli wśród nich niedźwiednicy bawiący dzieci, muzycy obsługujący wesela i festyny, najmowani przez gromadę lub parafię nauczyciele, kominiarze, kotlarze, pracownicy żniwni, ludzie najmowani do sianokosów i zbierania winorośli, kamieniarze, kopacze, wyplatacze koszy czy szklarze. Ich sieci społeczne obejmowały nie tylko migrantów i osoby żyjące w miejscu pracy, ale też ludzi mieszkających wzdłuż pokonywanych cyklicznie traktów, co wpływało na poprawę bezpieczeństwa wędrówki (s. 80-84).

Rzemieślnicy mieli nieco inne wzorce mobilności niż sezonowi robotnicy. Jako czeladnicy przez kilka lat między zakończeniem praktyki a ożenkiem przemieszczali się pomiędzy kolejnymi mistrzami w różnych osadach. Poza miastami, gdzie rzemiosło było ujęte w strukturze korporacyjnej cechów, niewiele wiadomo o życiu czeladników. Kilkuletni okres migracji wiejskiego rzemieślnika kończył się na ogół wraz ze stabilizacją, osiągnięciem pozycji mistrza, osiedleniem się gdzieś na przedmieściu, na wsi czy w miasteczku jako wolny od kontroli cechowej profesjonalista. Niektórzy porzucali wyuczony zawód. Jak bardzo mobilna była to grupa, świadczy, że we wszystkich kategoriach zawodowych w miastach około $80 \%$ czeladników było migrantami, a jedynie około $50 \%$ mistrzów pracowało poza miejscem urodzenia. W rzeczywistości jednak większość czeladników pochodziła z okolic miasta, gdzie podjęli praktykę. Według Hayhoe’a opinie o ludziach wędrujących dla specjalizacji zawodowej po całym kraju są przesadzone, gdyż nawet $\mathrm{w}$ zawodach niezwiązanych z rolnictwem około połowa czeladników pochodziła z obszaru nie większego niż $50 \mathrm{~km}$, chociaż zmieniali miejsce zamieszkania nawet do kilku razy rocznie. Masowe przemieszczenia wiązały się na ogół z brakiem pracy w danym miejscu. Ruchliwość przestrzenna czeladników jest uznawana za największy strumień migracyjny Europy wczesnej nowożytności i udowadnia, że nie można badać wyłącznie migracji trwałych, skoro było bardzo dużo różnego rodzaju „mobilności półtrwałej” (semi-permanent). Niełatwo znaleźć ślad po wędrówkach rzemieślników wiejskich i ich krótkich pobytach w danym miejscu, gdyż jako nierezydenci nie byli notowani w spisach ludności, nie byli właścicielami nieruchomości i nie płacili podatków. Według autora wzorce mobilności praktykantów rzemiosła we wsi i w mieście były zbliżone. We wsiach burgundzkich $69 \%$ czeladników i 50\% mistrzów mieszkało poza miejscem urodzenia. Czeladnicy migrowali dalej niż mistrzowie (ich średnia odległość między miejscem urodzenia a rejestracją w sądzie wyniosła $96 \mathrm{~km}$; mediana: $32 \mathrm{~km}$ ). Przy okazji dodajmy, że autor nie podjął głębszej analizy zawodów rolniczych i spożywczych w kontekście gospodarki wiejskiej i transportu (s. 87-88).

W przeciwieństwie do pracowników sezonowych pokonujących cyklicznie dłuższe dystanse w migracji czasowej krótkodystansowej najważniejsza 
rola przypadła służbie domowej. Ci młodzi na ogół ludzie przebywali stosunkowo krótko w poszczególnych miejscach, jednocześnie niełatwo odnaleźć ich w źródłach. Wiadomo, że wzorce mobilności były podobne dla służących obu płci, a średni dystans migracji wyniósł $33 \mathrm{~km}$ (mediana: $13 \mathrm{~km}$ ). Oznacza to, że w obrębie poszczególnych, kilkunastowioskowych mikroregionów można było znaleźć pracownika do służby domowej. Podobny obszar naboru służących (10$15 \mathrm{~km}$ ) uzyskano dla Anglii oraz Szwecji tego czasu. Służący stanowili około 7\% nierodowitych mieszkańców we wsiach północnoburgundzkich. Z zeznań sądowych wynikło, że tylko $27 \%$ z nich pracowało w miejscowości urodzenia (s. 90 , 98-100). Wśród migrantów krótkodystansowych byli również pracownicy rolni, np. żniwiarze przybywający na parę dni, w tym wiele kobiet. Było tam również wielu ubogich robotników miejskich, dniówkowych pracowników oraz dzieci gospodarzy. Robotnicy przybywający na zbiór zboża czy wina liczyli średnio około 30 lat. Na dłużej osiedlali się robotnicy z odleglejszych osad, głównie młocarze, rzadziej osoby pielące konopie, i byli to głównie mężczyźni liczący około 26 lat, wywodzący się z ubogich rodzin chłopskich. Starsze osoby zapewne pozostawały w miejscu zamieszkania, by pracować przy zbiorach.

Tego typu sezonowe przepływy siły roboczej wynikały z możliwości „dorobienia" sobie w okresowej zwyżce podaży pracy i zarobków lub z chwilowego przestoju na lokalnym rynku pracy. Dlatego np. młocarze pojawiali się we wsi na kilka zimowych dni czy tygodni od grudnia do marca, kiedy ich osada nie była w stanie zapewnić im całorocznego zatrudnienia. Dystanse pokonywane przez młocarzy były dość znaczne i wynosiły około $34 \mathrm{~km}$ (mediana). Okresowa praca $\mathrm{w}$ rolnictwie była również szansą na dodatkowy zarobek dla rzemieślników, głównie z małych miast. Pokonywali oni w tym celu krótsze dystanse niż pracownicy sezonowi ogółem (mediana: $8 \mathrm{~km} \mathrm{w}$ stosunku do $12-15 \mathrm{~km}$ ), blisko mogli znaleźć pracę zwłaszcza przy żniwach $(5-7 \mathrm{~km})$. Oznacza to, że rosnące gwałtownie okresowe zapotrzebowanie na pracowników żniwnych zapewniały najbliższe osady. Chociaż rotacja była znaczna, niektórzy migranci przez całe lata chodzili na żniwa do tego samego miejsca. Na tygodniowe winobranie wyruszali ludzie w każdym wieku i obojga płci, niekiedy całe rodziny, pokonując nawet $50 \mathrm{~km}$. Pojawiało się pośrednictwo pracy sezonowej, np. gospodarz zatrudniał człowieka, który odpowiadał za zebranie załogi, zebranie zbiorów i wypłatę wynagrodzenia robotnikom. Istniały także giełdy (targi) pracy na wsiach i miasteczkach, na których żniwiarze mogli znaleźć pracodawcę. Na podstawie dostępnych źródeł autor nie był w stanie powiedzieć tyle samo o sezonowym odpływie mieszkańców Burgundii na inne tereny co o napływie migrantów, jednak uznał, że tych drugich było więcej. Burgundczycy wyprawiali się na ścinkę drewna i do pracy w tartakach i pozostawali relatywnie blisko domu przez kilka tygodni. Niewielu z nich ruszało dalej, by na przykład pracować przez kilka 
miesięcy w winnicach i ogrodach okolic Paryża. Miejscowi chłopi pracowali też sezonowo w charakterze woźniców, np. wożąc zaprzęgami przez kilka miesięcy w roku drewno do odległego o około 300 km Paryża. Kobiety zatrudniały się w mieście jako mamki, ale także w tym celu zabierały dzieci mieszczan na wieś ${ }^{10}$. Hayhoe znalazł ciekawe rozwiązanie dla przybliżenia sezonowej nieobecności robotników w domu, polegające na analizie natężenia poczęć dzieci tych osób w trakcie roku. Wynikło z tego, że większość potomstwa murarzy poczęła się od listopada do marca, kiedy panował martwy okres w ich zawodzie i zapewne pozostawali w domu rodzinnym. Nie ma dowodów, by władze lokalne blokowały sezonowy przepływ siły roboczej, a tylko niektóre departamenty spisywały migrantów okresowych (s. 93-94).

Osobną grupą migrantów byli ludzie przybywający za pracą do lasów Burgundii. Zaszyci z dala od wsi rolniczych przy wytwarzaniu węgla drzewnego bywali traktowani gorzej przez ludzi miejscowych, jednak w jednym miejscu przebywali podobnie długo jak migrujący rolnicy, bo około 14 lat, stąd też z czasem zaczynali się integrować z miejscowymi rolnikami. Połowa pracowników leśnych wydała swe dzieci za potomstwo chłopów, głównie zagrodników, chociaż zdarzało się wżenianie w rodziny gospodarzy i wiejskich rzemieślników, zwłaszcza tkaczy. Takie wspólne wesela były okazją do dalszej integracji, co wynika chociażby z doboru świadków ślubu. Praca w leśnych przysiółkach nie izolowała zatem od pobliskiej wsi. Na koniec autor wskazuje, że w strumieniach migrantów sezonowych trudno wyłowić biedotę, bezdomnych i żebraków. Społeczności osiadłych rolników były dość tolerancyjne dla takich ludzi, zwłaszcza jeżeli pochodzili oni z najbliższej okolicy lub byli w jakiś sposób znani mieszkańcom. Areszt stosowano raczej wobec obcych włóczęgów, chociaż niektórzy z nich twierdzili, że nie są żebrakami, tylko szukają pracy (s. 95-98).

Rozdział piąty został poświęcony omówieniu motywacji migrantów do przemieszczenia zgodnie z teorią czynników wypychających i przyciągających Everetta Lee. Dla badanego okresu nie ma zbyt wielu źródeł pozwalających w sposób właściwy zbadać ten problem. Historycy migracji zakładają przewagę czynników ekonomicznych, nie sposób jednak ustalić właściwych proporcji. Brakuje też wypowiedzi zwykłych ludzi. Wyjściem było tu odniesienie się do typów osobowych migrantów, pokonywanych dystansów i cech społeczności, do których napływano. Chociaż migranci zamożni mogli podjąć dalsze wędrówki, biedni czynili to częściej na krótszych dystansach, gdzie koszty migracji były niższe. Obie grupy mogły wszakże wybierać miejsca z lepszymi warunkami ekonomicznymi: niższymi podatkami, polityką lokalną dopuszczającą przybyszy do korzystania

${ }^{10}$ George D. Sussman, Selling Mother's Milk: The Wet-Nursing Business in France, 17151914 (Urbana: University of Illinois Press, 1982), 51. 
z dóbr wspólnych, niewielkimi obowiązkami wobec dworu i dostępnością pracy. Pomocne tu okazało się analizowanie mobilności w kontekście umiejętności pisania i zamożności. Porównanie 535 ludzi, którzy złożyli podpisy w sądzie (nie więcej niż połowa świadków posiadała tę zdolność) ukazało, że przybysze (mężczyźni) byli tylko nieco mniej zamożni (o około 10-15\%) od osób miejscowych, ponadto było wśród nich mniej osób posiadających zdolność pisania (37\%) niż wśród zamożnych i osiadłych gospodarzy (44\%). Badanie nie pozwoliło jednak na ocenę zamożności służby domowej i niższych kategorii społecznych. Umiejętność podpisania się oznaczała więc ludzi zamożniejszych, zwłaszcza oraczy i winiarzy, np. rodziców będących w stanie zapewnić dziecku edukację. Wskazuje to również na zdolność do podejmowania większych operacji finansowych i pewną przedsiębiorczość. Z małej liczby kobiet w tej grupie J. Hayhoe wysnuwa wniosek, że rodzice przykładali większą wagę do edukacji synów. Więcej piśmiennych było wśród kobiet niezamężnych (np. praczki), ale większość córek ubogich chłopów, które porzuciły życie na służbie i wyszły za mąż, nie były w stanie się podpisać. Badacz ustalił jednak wzrost piśmienniczości kobiet z 9\% do $19 \%$ w ciągu badanego okresu. Natomiast w kategorii chłopów zamożnych częściej przemieszczali się właściciele mniejszych gospodarstw, chociaż to najbogatsi i piśmienni pokonywali duże dystanse, przekraczające $50 \mathrm{~km}$. Do gospodarstwa słabiej niż ich właściciele byli przywiązani dzierżawcy i w łatwiejszy sposób mogli szukać lepszych warunków najmu. Posiadanie ziemi było więc dla rolników czynnikiem ograniczającym migrację, gdyż aby się przenieść, musieli oni sprzedać niekiedy kawałki ziemi posiadane w różnych okolicznych wsiach i jednocześnie nabyć wystarczający areał w nowym miejscu dla prawidłowego funkcjonowania gospodarstwa. Wydłużało to nieraz migracje na dziesiątki kilometrów. Łatwiej było dokonać takiej zmiany winiarzom. Analiza antroponimów właścicieli dziedziczących gospodarstwa w poszczególnych osadach przez kilka dekad ukazała, że pomimo ich względnej stabilności nie gwarantowały one zupełnej osiadłości (s. 102-107).

W przeciwieństwie do mężczyzn więcej kobiet piśmiennych migrowało niż pozostawało w świecie lokalnym. Wynika to głównie z faktu, że ponosiły one mniejsze koszty ekonomiczne migracji, a jak twierdzi J. Hayhoe, migracja mogła być nawet formą nagrody.

W podziale migrantów na posiadaczy nieruchomości i innych na podstawie 14712 rekordów z rejestrów podatkowych jedynie 137 osób operujących działkami okazało się zdatnych do przedmiotowej analizy. Osoby zbywające nieruchomości aktywnie szukały lepszych warunków ekonomicznych, a połowa z nich zmieniła zawód wraz z migracją. Tyle samo doświadczyło awansu zawodowego (np. z robotnika dniówkowego na chłopa małorolnego, z chłopa małorolnego na gospodarza samowystarczalnego, w mniejszej liczbie z rolnika na rzemieślnika). Istniał 
związek migracji takich osób z niższymi podatkami w nowym miejscu pobytu. Dotyczy to ludzi mających trudności ekonomiczne i szukających szans w innych gałęziach gospodarki. Historycy migracji często dzielą analizowane osoby na migrantów szukających warunków do przeżycia i migrantów chcących polepszyć warunki życia, ale ścisłe rozróżnienie nie jest możliwe, gdyż np. migracja sezonowa z gór na niziny nie musiała być skutkiem przeludnienia i ubóstwa, a świadomym wyborem. Jak już dowiedziono, migracji w Burgundii często towarzyszyła zmiana statusu społecznego bądź zawodowego. Wraz z przemieszczeniem spadała presja ekonomiczna, ale wzrastała mobilność społeczna (pionowa) we wszystkich kategoriach społeczeństwa. Krótkodystansowi migranci pod koniec swego życia byli zamożniejsi niż ich rodzice, chociaż sami migranci byli ubożsi niż pozostawieni w wiosce osiadli członkowie społeczności, a podobnie rzecz się miała ze wskaźnikiem alfabetyzacji. Nie oznacza to oczywiście, że we wsi zostali wyłącznie ludzie bogaci i posiadający ziemię, a w drogę wyruszali biedni.

Do rzadkości należy źródło zawierające dane o emigracji. Źródła do historii migracji wewnętrznych dotyczą zwykle przybyszy, gdyż społeczności lokalne były bardziej zainteresowane ich przeszłością niż dalszym losem osób, które opuściły zamieszkiwane miejsce. Autor miał dostęp do takiego źródła w postaci kilkuset rejestrów osób opuszczających miasto Dijon i na tej podstawie ustalił, że większość migracji cechowała nietrwałość, ale procesy te powodowały znaczące zmiany w życiu codziennym migrantów. Wspomniane materiały dotyczą ludzi zamożnych i płacących podatki, jednak nie obejmują młodych i ubogich migrantów, jak żeńska służba domowa, która przybywała do miasta na kilka lat i wracała do wsi rodzinnej lub okolicy. Dzięki rejestrom z Dijon można było jednak ustalić, że migracja z miasta na wieś nie była rzadkim zjawiskiem. Większość z przybyszy do miasta powróciła na tereny wiejskie lub do miasteczek (aż 70\% migrantów), a co dziesiąty wybrał duże miasto. Byli tam i ludzie przenoszący się na stare lata do swych dzieci mieszkających na wsi. Dystans migracji miejsko-wiejskich był dwukrotnie większy niż międzywiejskich (średnia: $35 \mathrm{~km}$; mediana: $24 \mathrm{~km}$ ), ale wiele osób osiadało blisko, we wsiach pod Dijon. Z deklaracji migrantów najważniejszymi przyczynami wyprowadzki z miasta były kwestie ekonomiczne, rezygnacja z pracy (np. w związku ze starością), zamieszkanie u potomstwa na wsi, a także warunki zdrowotne. Byli to ludzie niedawno owdowiali lub niezdolni do samodzielnego utrzymania, także młodsi, ale niepełnosprawni, osiadający u swych rodziców lub rodzeństwa. Ludzie tacy próbowali podjąć się służby domowej na wsi czy osiąść w klasztorze. Jako inne przyczyny podawano również trudności finansowe, wysokie podatki, problemy z pracą czy po prostu powrót do miejsca urodzenia, np. w związku z dziedziczeniem. Zapewne większość ludzi odeszła do wsi, w których wcześniej już mieszkała. J. Hayhoe podkreślił, że migracje miejsko-wiejskie i tzw. kontrstrumienie migracyjne (counter-streams) 
wymagają dalszych badań. Dla migracji na wsi burgundzkiej znaczenie miało także miejsce w cyklu życia (dojrzewanie, małżeństwo, starość), śmierć rodziców, choroba, lepsza praca, chęć przygody lub uniknięcia odpowiedzialności karnej bądź kwestie związane z zebraniem środków na posag, kiedy ubodzy rodzice nie byli w stanie zapewnić go swej córce (s. 107-113).

Szósty rozdział został poświęcony czynnikom przyciągającym migrantów i geografii migracji wewnętrznych. Okazało się, że prócz barier geograficznych (wzgórza, rzeki) znalazły się i takie, jak możliwości ekonomiczne, lokalna polityka podatkowa (nie dotyczyło to osób pracujących czasowo bez zamiaru trwałego osiedlenia), system zarządzania ziemią i oferta dostępu do dóbr wspólnych (np. lasy, kamieniołomy, pastwiska) czy siła poddaństwa. Zgodnie z modelem grawitacyjnym więcej osób nierodowitych zamieszkiwało wsie leżące bliżej miast niż na prowincji. Autor zobrazował te zjawiska na odpowiednio przygotowanych mapach. W dalszej kolejności uznał, że sieci społeczne międzywiejskie nie były tak silne jak wiejsko-miejskie, a przybysze na wieś reprezentowali różnorodne miejsca pochodzenia. Mocniej na sieciach społecznych były oparte migracje sezonowe, a migranci długookresowi mogli po prostu kierować się potrzebą zerwania z poprzednimi więziami społecznymi (s. 129-133). Migrujący i posiadający zwierzęta hodowlane drobni rolnicy poszukiwali okolicy z pastwiskami, chociaż tu mogli się spotkać z blokowaniem dostępu przez miejscowych chłopów (s. 140142). W podsumowaniu tej części rozważań J. Hayhoe zauważa, że za mnogością przemieszczeń wewnętrznych w Burgundii stały głównie indywidulane decyzje dotyczące tego, czy i gdzie się przenieść. Były to raczej rodzinne strategie obejmujące kalkulację kosztów migracji niż działanie przypadkowe. Najważniejsze znaczenie miały warunki ekonomiczne, zwłaszcza dla ludzi młodych i kobiet, grup najmniej przywiązanych do ziemi (s. 146-147).

Siódmy rozdział poświęcono polityce lokalnej społeczności względem migrantów i ich integracji w nowym miejscu. Jak już powiedziano, większość mieszkańców w trakcie swojego życia spędzała przynajmniej kilka lat poza miejscem urodzenia. $Z$ powodu znacznej ruchliwości przestrzennej społeczności lokalne musiały regulować na bieżąco kwestię rezydencjonalności. Z wyjątkiem wsi z większymi zobowiązaniami poddańczymi (serf villages) w północnej Burgundii funkcjonował wolny rynek migracyjny, ale mieszkańcy nie mieli równego statusu. Nawet dekada zamieszkania od chwili migracji mogła nie wystarczyć do zdobycia pełnego zaufania lokalnych czynników politycznych, nie mówiąc o wejściu do wewnętrznego kręgu społeczności wiejskiej, który podejmował decyzje co do lokalnych zasobów. Była to zrozumiała reakcja na stałą obecność dużej liczby czasowych mieszkańców we wszystkich społecznościach wiejskich. Poza restrykcjami odnoszącymi się do migrującego elementu kryminogennego regulacja przepływu ludności opierała się na stosownym opodatkowaniu i podziale 
korzystania z dóbr wspólnotowych. Pilnowano, by obciążenia podatkowe były spłacane równomiernie. Na miejsce opuszczone szukano właściwego gospodarza, a bycie płatnikiem umożliwiało dostęp do zasobów wsi ${ }^{11}$. W przypadku napływu osób uboższych ważna była kontrola dostępu do instytucji wsparcia społecznego, a także utrzymania porządku publicznego. Podobnie jak w innych obszarach Europy lokalna administracja próbowała egzekwować od przybyszy, zwłaszcza wynajmujących kwatery, strychy i piwnice zaświadczenia o poprzednim miejscu pobytu i zatrudnieniu, moralności; brak takowych zaświadczeń mógł być powodem wydalania migrantów. Nie było jednak łatwo kontrolować w ten sposób całej przepływającej ludności, więc odpowiedzialność za to starano się przenieść (podobnie jak w nowożytnych miastach) na mieszkańców wynajmujących przybyszom lokale. Ci jednak nie zawsze zgłaszali swej jurysdykcji brak takich zaświadczeń; czynili to bądź z życzliwości, bądź z pazerności lub ujawniali to dopiero wtedy, gdy nabierali do przybysza podejrzeń. Takie ukrywanie stanowi problem dla historyka migracji, gdyż pozbawia go informacji o ważnym aspekcie badań, tym bardziej, że miały też miejsce nieformalne regulacje przepływu migrantów. W podsumowaniu autor wskazuje, że władze dystryktu Dijon nie zabraniały migrowania, a starały się je w miarę dokładnie uporządkować. Zakazywano nakładania lokalnych opłat odstręczających od przemieszczania się, gdyż ważniejsze było pozyskiwanie nowych podatników (s. 160-163).

Pomimo masowych, krótkodystansowych przepływów wewnętrznych we wsiach burgundzkich J. Hayhoe jest daleki od konstatacji, że lokalną tożsamość budował mikroregion, a nie dana wieś. Były rodziny żyjące we poszczególnych osadach przez całe pokolenia, prawdziwe dynastie zawiadujące najważniejszymi sprawami wsi. Głos tak chętnie przyjmowanych uboższych od nich migrantów czasowych niewiele znaczył, choć formalnie każdy mieszkaniec mógł brać udział w zebraniach i zgłaszać swoje opinie zwierzchności urzędowej. Liczyła się przede wszystkim przynależność do jednej miejscowości, w której posiadano nieruchomość i płaciło się podatki (używano tej informacji nawet przy określaniu pochodzenia migrantów) (s. 165-166). Oczywiście panowały przekonania, że przybysze pojawiają się w efekcie jakiś przestępstw dokonanych w poprzednim miejscu pobytu czy niesnasek i lepiej traktowano obcych z pobliża, o których czegoś można się było dowiedzieć (to również potwierdza niewielki zasięg egzogamii małżeńskiej). Stawanie się człowiekiem miejscowym oznaczało akceptację wspólnego ponoszenia kosztów, zamieszkanie w osadzie, zdobycie pracy, ściągnięcie lub założenie rodziny i nabycie nieruchomości, czyli otwarcie się na lokalną wspólnotę. Przykładowo obywatelstwo we francuskim mieście Aix-en-Provence tłumaczono

${ }^{11}$ Por. Józef Rafacz, Ustrój wsi samorzadnej małopolskiej w XVIII wieku (Lublin: Uniwersytet Lubelski, 1922), 12. 
w ten sposób, że człowiek obcy to nie ten, co jest skądinąd, ale ten, co nie przestaje być skądinąd. W Mediolanie obcym był każdy, kto nie mieszkał na stałe z rodziną w mieście, nawet jeśli był z pochodzenia mediolańczykiem (s. 169).

Mimo wyrażonych tu uwag miejscowi nie uważali ludzi napływowych za zupełnie obcych, a status mieszkańca można było uzyskać, uczestnicząc w życiu społeczności lokalnej. Wiadomo również, że migrantom w drugim pokoleniu było znacznie łatwiej niż ich rodzicom, ale już uzyskanie stanowiska urzędniczego we wsi było dostępne głównie dla osób rodowitych (65\% spośród badanej grupy około 2000 mężczyzn). Dostęp do wewnętrznego kręgu wsi i elity władzy był nieco łatwiejszy dla obcych, którzy wstąpili w związek małżeński z miejscowymi kobietami (s. 170-171). Urzędnicy lokalni musieli być godni zaufania, gdyż odpowiadali za zbiór podatków i podejmowali najważniejsze decyzje we wsi; ważne też, by wiadomo było, że nie odejdą w najbliższym czasie gdzie indziej. To rodowici mężczyźni i małżonkowie miejscowych kobiet faktycznie mieli sprawczy głos w zebraniach wiejskich, współtworzyli zręby lokalnej sieci społecznej. W większości bowiem migracje były nietrwałe, dlatego młodocianych, ludzi samotnych, służby domowej i pracowników niewykwalifikowanych w dobrze pojętym interesie lokalnej wspólnoty należało się strzec (s. 174-175). Autorowi trudno było pokazać, jak działały mechanizmy asymilacji, poza analizą na podstawie źródeł pośrednich. Chociaż nie istniały formalne zakazy przyjmowania legalnych, wylegitymowanych migrantów, zwłaszcza dopóki wyrażali chęć uczestnictwa w życiu zbiorowym i płacenia podatków, linia między zewnętrznym i wewnętrznym kręgiem wsi była czytelna (s. 175-177). Po publicznym potwierdzeniu zmiany miejsca zamieszkania, nabycia nieruchomości, wejściu w krąg podatników tracono niejako automatycznie status nieznajomych. Proces stawania się miejscowym obywatelem, a więc zdobycie zaufania rezydentów, nie oznaczał jednak zupełnej asymilacji.

W mojej ocenie książka Jeremiego Hayhoe stanowi cenny wkład w badania nad historią migracji i wpisuje się $\mathrm{w}$ aktualny problem zgłębiania zjawiska migracji wewnętrznych i mikromobilności, które miały przemożny wpływ na urbanizację i ogólną mobilność ludzką. Przybliżając rolę migracji krótkodystansowych w życiu chłopów, J. Hayhoe zakwestionował pogląd Charlesa Tilly'ego, że z definicji migracja musi obejmować duży dystans, być definitywna i zrywać więzi z miejscem pochodzenia. Migracje krótsze nie wymagały wielkich przygotowań, ale przez swą częstotliwość przyczyniały się do zmiany społecznej, co potwierdzają badania innych historyków migracji, takich jak C. Pooley, J. Turnbull czy S. Hochstadt (s. 77-78). Zaletą książki jest wejście w słabiej rozpoznany obszar wiejskich migracji, dla których dysponujemy gorszymi źródłami niż w przypadku badania miast. Co więcej, przybliżenie analiz wykonanych dla Francji na nieco słabszych materiałach niż angielskie pozwala określić, jakich wyników można 
się spodziewać dla Polski, gdyż nie sądzę, by mogła być ona „samotną wyspą” w masie przemieszczeń Europejczyków wczesnonowożytnych.

Zasługą J. Hayhoe’a jest pomysłowy dobór źródeł i zmierzenie się z potężnym, nominatywnym materiałem statystycznym. Autor musiał sobie poradzić z takimi problemami, jak łączenie informacji o ludziach poza podstawowymi więziami (dzieci-rodzice, służba-gospodarze, uczniowie rzemiosła-mistrzowie) czy ukazanie więzi rodzinnych młodzieży ze świadkami ślubów i chrztów. Do zbadania wzorców migracji w wiejskiej Francji przybliżyło go mieszanie informacji z różnych źródeł, zmienianie skali obserwacji i dobór różnych metod. Książka zawiera również dobrze dobraną i szeroko omówioną literaturę przedmiotu. Przeprowadzone kwerendy biblioteczne i archiwalne, wprowadzanie wielotysięcznych baz danych ze spisów ludności i ksiąg metrykalnych (głównie śluby, ale też chrzty i pogrzeby) odbyło się dzięki wydatnej pomocy studentów i towarzystw genealogicznych. Przy budowaniu georeferencji i map autor korzystał z pomocy profesjonalnego geografa (s. VIII).

Praca Hayhoe’a dowodzi, że mobilność chłopów burgundzkich była bardzo duża, dotyczyła w zasadzie wszystkich mieszkańców, chociaż w różnym stopniu, i przemieszczeń na stosunkowo niewielkich dystansach. Można wyróżnić różne grupy migrantów, ale większość po czasowym zamieszkaniu na badanym obszarze przemieszczała się dalej. Pomimo istniejących gdzieniegdzie formalnych ograniczeń migracji zwykli ludzie mogli się przemieszczać i zamieszkiwać, gdzie im się podobało. Wymagało to jednak od lokalnych społeczności pewnych nieformalnych prób ograniczania dostępu do swych dóbr. W „mikroświatach” chłopów burgundzkich, obejmujących kilkuwioskową przestrzeń, mieszkańcy zajmowali się swoimi codziennymi sprawami, dotyczącymi edukacji, praktyki i pracy, zakupów i sprzedaży oraz socjalizacji. Przemieszczenia opierały się na rozbudowanych sieciach społecznych, natomiast większość ludzi, którzy migrowali na dystansie większym niż $10 \mathrm{~km}$, traciła regularny kontakt z krewnymi. Migracja wiązała się ze zmianami w zamożności i zawodzie. Z miejsca zamieszkania wypychały niekorzystne warunki ekonomiczne, a sama migracja wywoływała wiele poważnych zmian w życiu codziennym. Dla młodych migrantów wyjątkowo ważnym, bo formującym podstawy dalszych doświadczeń życiowych poza domem, było pierwsze wyjście, przemieszczenie się na kontrakt służebny. Wpływ tego wyjścia na tożsamość migranta można przyrównać do zawarcia małżeństwa egzogamicznego. Chociaż dla migranta matrymonialnego łączyło się to z pewnym osłabieniem własnych korzeni, zapewniało z reguły dostęp do społecznej sieci wsparcia w nowym miejscu zamieszkania lub/i założenia rodziny. Migracja była szansą na poprawę losu także dla ludzi starych lub owdowiałych, niemogących już dłużej zadbać o siebie w miejscu dotychczasowego 
zamieszkania i nieznajdujących dostatecznego wsparcia rodziny, lokalnej społeczności i instytucji. Migracja związana była z pewnymi, niekiedy dość wysokimi kosztami (społecznymi, rodzinnymi, ekonomicznymi), zwłaszcza z utratą kapitału społecznego, np. niemożnością osiągnięcia zupełnej akceptacji jako stały członek nowej społeczności wiejskiej. Rodowici chłopi we wsiach burgundzkich lepiej akceptowali przybyszy, o których przodkach, poprzednikach lub po prostu o przyczynach migracji już coś wiedzieli. Najważniejszym czynnikiem motywującym do migracji była chęć zapewnienia lepszych warunków życia, towarzysząca jednostce od młodzieńczych lat, kiedy podejmowano naukę i pierwszą pracę, do późnej starości. Dotyczyło to również rodzin, gdyż w Burgundii dominowała rodzina nuklearna, a działki były na ogół rozdrobnione. Stąd też każde pokolenie producentów rolnych musiało odtwarzać gospodarstwa. To zaś generowało ludzką mobilność.

\section{Bibliografia}

Clark, Peter, David Souden. Wstęp do: Peter Clark, David Souden, red., Migration and Society in Early Modern England, 11-48. London: Hutchinson, 1987.

Hochstadt, Steve, Mobility and Modernity: Migration in Germany, 1820-1989. Ann Arbor: University of Michigan Press, 1999.

Kümin, Beat. „Public Houses and Their Patrons in Early Modern Europe”. W: The World of the Tavern: Public Houses in Early Modern Europe, red. Beat Kümin, B. Ann Tlusty, 44-62. Aldershot, UK: Ashgate, 2002.

McCants, Anne. „Internal Migration in Friesland, 1750-1805”. Journal of Interdisciplinary History 22 (1992): 387-409.

Montenach, Anne. „Legal Trade and Black Markets: Foodtrades in Lyon in the Late Seventeenth and Early Eighteenth Centuries". W: Female Agency in the Urban Economy: Gender in European Towns, 1640-1830, red. Deborah Simonton, Anne Montenach, 17-33. New York: Routlege, 2013.

Pooley, Colin G. „Local Histories of Migration and Mobility”. Local Population Studies 100 (2018), 1: 52-59.

Pooley, Colin G., Jean Turnbull. Migration and Mobility in Britain since the Eighteenth Century. London: UCL Press, 1998.

Rafacz, Józef. Ustrój wsi samorząnej matopolskiej w XVIII wieku. Lublin: Uniwersytet Lubelski, 1922.

Ravenstein, Ernst Georg. „The Laws of Migration”. Journal of the Statistical Society 48 (1885), 2: 168-235.

Ravenstein, Ernst Georg. „The Laws of Migration, Second Paper”. Journal of the Royal Statistical Society 52 (1889), 2: 241-305. 
Ruggles, Steven. „Migration, Marriage, and Mortality: Correcting Sources of Bias in English Family Reconstitutions". Population Studies 46 (1992), 3: 507-522.

Sussman, George D. Selling Mother's Milk: The Wet-Nursing Business in France, 17151914. Urbana: University of Illinois Press, 1982.

\section{Ludzie rodowici i migranci - czy słuszny podział? Wokół książki Jeremy’ego Hayhoe'a Strangers and Neighbours. Rural Migration in Eighteenth-Century Northern Burgundy, Toronto: University of Toronto Press, 2016, ss. 274}

\section{Streszczenie}

Autor recenzowanej książki dowiódł, że na gorzej zachowanych niż w przypadku czasów późniejszych materiałach źródłowych z epoki przednowoczesnej, takich jak pierwsze spisy ludności, zeznania świadków w sądach i księgi metrykalne można prowadzić badania nad historią migracji. Jeremy Hayhoe ustalił powszechność doświadczenia migracji w życiu mieszkańców wsi północnoburgundzkiej, udowodnił również ich gotowość do przemieszczeń, związanych najczęściej z kwestami ekonomicznymi, zwłaszcza podejmowanym okresowo zatrudnieniem i poszukiwaniem lepszych możliwości życiowych (niższe podatki, wyższe wynagrodzenia i dostęp do dóbr wspólnotowych). Do rzadkości należało trwałe zamieszkanie człowieka w tej samej osadzie od urodzenia do zgonu bez choćby czasowej migracji, trudno zatem o prosty podział ludności na osoby rodowite i przybyszy, zwłaszcza jeżeli pojęcie migracji rozszerzymy o tzw. mikromobilność. Migracje zależały od stopnia zamożności migrantów, ich zawodu i wykształcenia. Istniały też pewne różnice w zależności od płci. Ubożsi najczęściej poszukiwali zatrudnienia w najbliższej okolicy w celu biologicznego przetrwania. Bogatsi migrowali rzadziej, ale pokonywali dłuższe dystanse dla polepszenia standardów życia. Ustalony przez badacza na $10 \mathrm{~km}$ w linii prostej zasięg przestrzenny, w jakim mieszkańcy wsi spędzali swą codzienność, znajdowali zatrudnienie i załatwiali większość koniecznych spraw, był jednak często przekraczany. O ile większość służby domowej pracowała poza rodzinnym domem, ale w najbliższej okolicy, o tyle rzemieślnicy, winiarze i kupcy pokonywali dalsze dystanse. W omawianym zjawisku istotną rolę odgrywały społeczności lokalne, które przyjmowały migrantów. 


\section{Natives and Migrants - a Correct Categorization? Some Reflections on Jeremy Hayhoe's Book Strangers and Neighbours. Rural Migration in Eighteenth-Century Northern Burgundy, Toronto: University of Toronto Press, 2016, pp. 274}

\section{Summary}

It turns out that research on the history of migration can also be conducted on the basis of source material that is not preserved in sufficient quantities for the premodern era, such as the earliest censuses, witness testimonies taken in court, and birth, marriage and burial records. The author of the book under review has established that the experience of migration was common in the lives of rural communities in northern Burgundy. He has also demonstrated their readiness to move, in most cases occasioned by economic issues, especially periodic employment and search for better life opportunities (lower taxes, higher pay, and access to community assets). Cases of individuals living permanently in the same settlement from birth to death, without at least temporary migration during their lifetime, were rare. Hence the difficulty in accepting a simple categorization of the population into natives and newcomers, especially if we extend the concept of migration to include what is known as micromobility. Migration was determined by the level of the migrants' wealth, their occupation and education. There were also some differences in terms of gender. The less affluent usually sought employment in the nearest areas to assure biological survival for themselves. Wealthier individuals were less inclined to migrate but when they did, they tended to cover longer distances to improve their living standards. The distance of 10 kilometres as the crow flies, established by the researcher as the spatial reach within which the rural populations lived their everyday lives, found employment and attended to most of their vital affairs was, however, often surpassed. While most domestic servants worked outside their family home but still in its vicinity, craftsmen, winemakers and merchants covered greater distances. In the phenomenon under review, an important role was played by the local communities who welcomed migrants. 